Special Issue: Agricultural Productivity and Sustainability Improvement in Tropical Region

\title{
Effect of Freeze-Drying Pressure and OperatingTime on Mass Balance and Characteristics of Freeze-Dried Mango Slices
}

\author{
Suherman Suherman ${ }^{1 *}$, Andhini Putri Trianita ${ }^{1}$ Hadiyanto Hadiyanto $^{1}$ and Wea Aanisah Mentari Putri ${ }^{2}$ \\ ${ }^{1}$ Department of Chemical Engineering, Faculty of Engineering, Diponegoro University, Jln. Prof. Soedarto, Tembalang, \\ Semarang, Jawa Tengah, 50275, Indonesia; ${ }^{2}$ Department of Food Science, Université Catholique de Lille, Groupe ISA, 48 \\ Boulevard Vauban, F-59046 Lille, France.
}

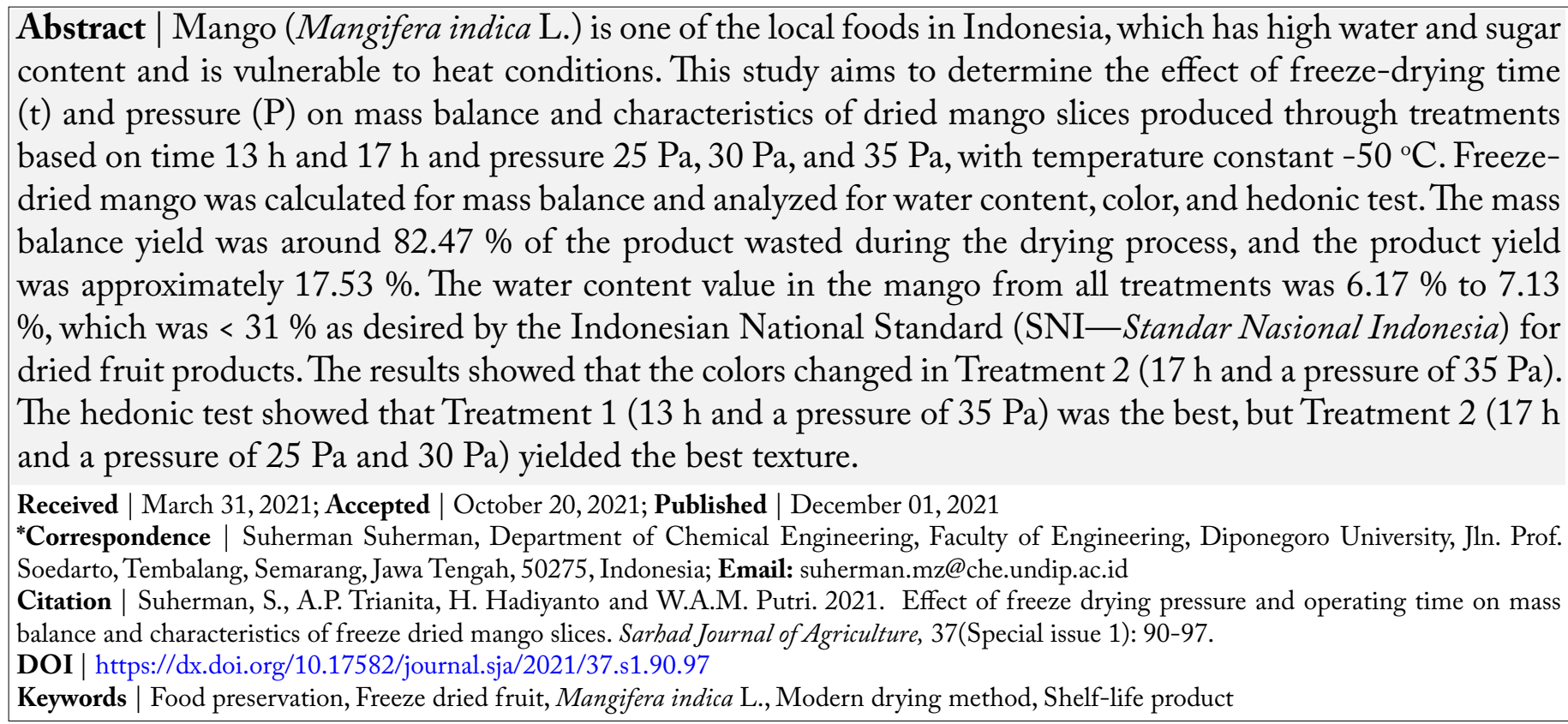

\section{Introduction}

$\mathrm{M}$ ango (Mangifera indica L.) is a fruit that can be found in tropical countries. Mango-producing countries in Asia include India, China, Thailand, Indonesia, and the Philippines. In general, this tropical fruit has many variants in each country. For example, Indonesia produces a variety of mangoes with a total of $1313540 \mathrm{t}$ every year and until now has been one of the world's largest producers of mangoes (Azizah, 2016).

Indonesia ranks 5th in the world's mango commodity producer, while the typical Indonesian variants are Arumanis143, Golek 31, and Manalagi 69. The three mango varieties can produce much fruit with thick flesh and taste sweet (Sandrawati et al., 2017). The Gadung, Gedong Gincu, and Gurib mangoes are among the popular varieties in Indonesia, with thick flesh and sweet taste (Rasmikayati et al., 2020).

The nutritional content of mangoes, in general, can be seen from two different categories: pre-harvest and post-harvest. The difference in the content of the two groups of mango is quite significant. The water content, minerals, and protein of raw mangoes are higher than the ripe mangoes, but the sugar, fiber, vitamins, and calories of ripe mangoes are higher than fresh mangoes. In contrast, lipid content in both categories is the same. 
Water and sugar content in mangoes can affect the shelf-life of the product. Food that has a high water content can accelerate the product expiry period. It is due to the formation of spoilage bacteria that spoil food quickly. That is why fresh mango can not be stored for a long time and is a perishable food (Rehman et al., 2021). Thus, an effective food preservation method is needed to prevent spoilage and food characteristic changes and extend the product's shelf-life by using a modern drying method such as a freeze dryer (Valentina et al., 2016).

Modern drying with the freeze-drying method is a process of a material or solution crystallized at low temperatures below freezing, which undergoes a sublimation process that changes solid-phase into steam. In general, the purpose of freeze-drying is to produce materials that have excellent stability and do not change even after adding water again (Fernando, 2009).

The freeze-drying method consists of two stages, namely primary drying and secondary drying. The main drying process is freezing the material after the material goes through the freezing process, marked by the formation of ice crystals. The next stage is the second drying process or further drying process. In the second drying, the sublimation process is followed by a desorption process, the last freeze-drying process, which is instrumental in producing the freeze-dried product. That is why the freeze dryer can work well in the drying process, which uses temperatures below freezing intending to maintain the stability of the structure of foodstuffs and the nutritional content of foods, especially those with high sugar content and cannot withstand hot temperatures. Moreover, according to Nawirska et al. (2009), the freeze-drying process can minimize the product quality change in color, taste, chemical composition, and texture.

On the other hand, freeze-drying has been applied for several agricultural products, like soursop-Annona muricata L. (Ceballos et al., 2012), apple-Malus domestica Borkh (Parniakov et al., 2016), gingerZingiber officinale Roscoe (An et al., 2016), acerolaMalpighia glabra L. (Marques et al., 2007), and mango-M. indica (Salazar et al., 2017). Researches have stated that freeze-drying can retain the physical properties of dried products. However, the freezedrying method is not without its limitations, as it requires an extended drying time, which translates into high energy costs (Liliana et al., 2015). Apart from drying time, the operating temperature and pressure also affect the product quality during freezedrying.

The suitability between variations in conditions between time and pressure can affect the characteristics of freeze-dried mango slices. Therefore, this study aims to determine the effect of time $(t)$ and pressure (P) of freeze dryer on the characteristics of freezedried mango slices, including moisture content, color, and hedonic test, through six treatments based on variations of time and pressure of freeze dryer.

\section{Materials and Methods}

For examination, this research obtained the Gedong Gincu mangoes from the Mango Plantation Center in Sliyeg Village, Indramayu Regency, West Java, Indonesia. First, the mangoes were sorted and washed before preparing the mango slices. Next, the mangoes were peeled and sliced using a knife with a thickness of $0.5 \mathrm{~cm}$, length of $6 \mathrm{~cm}$, and width of $5 \mathrm{~cm}$.

\section{Freeze-drying techniques}

This research uses a freeze dryer with type Buchi L-200 made in Germany for drying mangoes. The freeze-drying method uses a constant temperature of $-50{ }^{\circ} \mathrm{C}$ with varying pressures of $25 \mathrm{~Pa}, 30 \mathrm{~Pa}, 35 \mathrm{~Pa}$, and a time of $13 \mathrm{hr}$ and $17 \mathrm{hr}$.

\section{Moisture content}

Moisture content was analyzed using an oven WTB Binder with type FD 56. According to the AOAC (2000) method, the weight of the mango sample's initial and final dry matter was calculated. Thus, Equation (1) can calculate the value of the moisture content:

$$
M C=\frac{(\mathrm{Wi}-\mathrm{Wds})}{\mathrm{W}_{\mathrm{i}}(\% \text { wet basis })} \times 100 \ldots \ldots .
$$

Where;

$\mathrm{w}_{\mathrm{i}}(\mathrm{g})$ is the weight of the initial dry of mango slices before the oven process, and $\mathrm{w}_{\mathrm{ds}}(\mathrm{g})$ is the weight of the final dry of mango slices after the oven process on a dry basis.

\section{Mass balance}

The mass balance of the material is used to determine the amount of incoming material accumulated by the amount of material coming out (product) on a $100 \%$ basis. 
The mass balance calculation is used to identify and compose several streams that enter and exit the system. In this study, the system in question is the drying process using temperatures below freezing, which is $-50{ }^{\circ} \mathrm{C}$, and time and pressure variations. Therefore, an equation is needed to evaluate unknown variables in determining the flow entering and leaving the system. The basic mass balance calculation techniques in a system were based on the law of mass balance (Pramulya et al. 2019) in Equation (2) to Equation (6).

$$
\text { Mass }_{\text {input }}=\text { Mass }_{\text {output }}
$$

The equation is used if there is no additional chemical content that is put into the dryer (freeze dryer). How much product is produced after going through the drying process can be calculated with Equation (3):

Or

$$
\text { Mass }_{\text {in }}=\text { Mass }_{\text {out }}+\text { Mass }_{\text {wastelstorage }}
$$

$$
\text { Accumulation }(x)=\text { Mass }_{\text {in }}-\text { Mass }_{\text {out }}
$$

If the amount of accumulation is equal with product wastes, then the fraction of product weight (mass out) and the fraction of the accumulated material weight (x) can be calculated with Equation (5).

$$
\text { Mass fraction } A=x / \text { mass }_{\text {in }} \times 100 \% \text {. }
$$

\section{Where;}

$\mathrm{x}$ is accumulation weight of mass in and mass out $(\mathrm{g})$. Meanwhile, to get the value of the mass out fraction can use the following Equation (6),

$$
\text { Mass fraction }{ }_{\text {out }}=\text { Mass }_{\text {out }} / \text { Mass }_{\text {in }}
$$

Thus, the results obtained will show the same basis when the feed ingredients enter (mass in) and products (mass out).

\section{Color analysis}

A colorimeter spectrophotometric Hitachi UH 5300 spectrophotometer is used to analyze the color of freeze-dried mango for the total color testing parameter $(\Delta \mathrm{E})$. Color testing was carried out according to the method presented by Salazar et al. (2017). Besides that, the preferences color of freezedried mango slices was analyzed by observation.

\section{Sensory analysis}

Sensory analysis in this research used a hedonic test or test of preference to determine the level of liking or feasibility of a product accepted by panelists (consumers). The hedonic tests include the texture, color, taste, and aroma of the product. In this method, the panelists were asked to give a rating in the form of a score based on the level of liking to the product with the criteria: (1) highly dislike, (2) dislike, (3) rather like, (4) like, and (5) like very much (Ahmad et al., 2014). This test was conducted on ten trained panelists with a background in food technology in Universitas Diponegoro, Semarang City, Indonesia. The test was conducted according to SNI 01-23462006 (Badan Standarisasi Nasional, 2006).

The results of this study were analyzed with a qualitative method to see the quality of dried mango slices. First, the mass balance was analyzed in the mass balance standard equation. Then, the moisture content, color, and hedonic test were analyzed using a descriptive method using Microsoft Excel 2016 (Adinurani, 2016).

\section{Results and Discussion}

\section{Moisture content}

The results of moisture content analysis on freezedried mango sliced samples can be seen in Table 1 .

Table 1: Moisture content.

$\begin{array}{lllll}\text { Sample } & \begin{array}{l}\text { Initial } \\ \text { mass }(\mathbf{g})\end{array} & \begin{array}{l}\text { Pressure } \\ (\mathbf{P a})\end{array} & \begin{array}{l}\text { Final mass } \\ (\mathbf{g})\end{array} & \begin{array}{l}\text { Moisture } \\ \text { content (\%) }\end{array} \\ \begin{array}{l}\text { Treatment 1 } \\ \text { (13 h) }\end{array} & 293 & 25 & 57.16 & 6.91 \\ & & 30 & 56.80 & 7.01 \\ \text { Treatment 2 } & 35 & 54.70 & 7.13 \\ \text { (17 h) } & 25 & 47.90 & 5.46 \\ & & 30 & 49.13 & 5.50 \\ \text { Average } & & & 44.70 & 6.17 \\ \end{array}$

The results showed that the sample freeze-dried mango slices have different moisture content values. However, the results showed variation around 1.0 to 1.5 and were significant in affecting drying conditions. The highest water content was found in the freeze-dried mango slices sample in Treatment 1 , which was $13 \mathrm{~h}$ and a pressure of $35 \mathrm{~Pa}$. On the other hand, the lowest moisture content value was found in the freeze-dried mango slices sample in Treatment 2 with $17 \mathrm{~h}$ and a pressure of $25 \mathrm{~Pa}$.

The difference in results arose because time and operating pressure had a significant effect on the freeze dryers. The longer was the drying time, the lower was the water content in the material. On the 
other hand, despite the higher pressure in the freeze dryer, the water content in the material remains high. This is because the water in the material was difficult to dry, so water content remained trapped in the material. This is reinforced by the opinion of $\mathrm{Pu}$ and Sun (2015) that the drying process can affect the moisture content uniformity of dried products during drying processing and drying technique (heating and drying time). It can decrease the moisture content significantly. Thus, the sample's moisture content will be low at a relatively shorter time and vice versa.

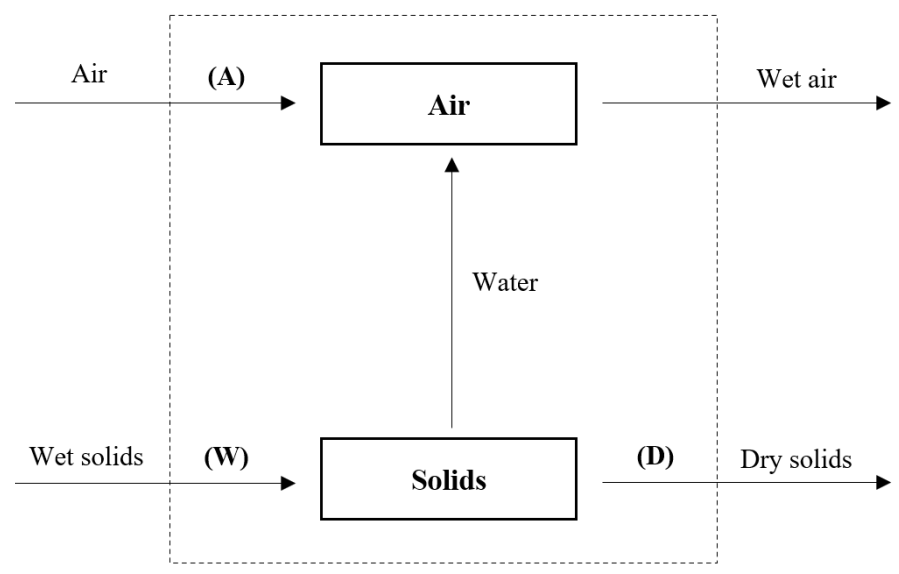

Figure 1: Material processing on drying.

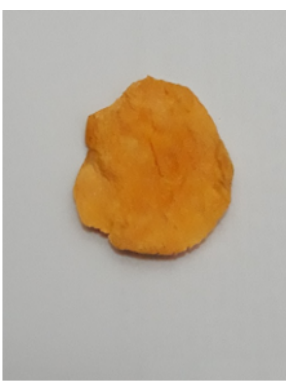

(a)

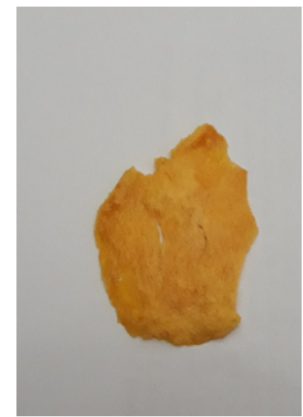

(d)

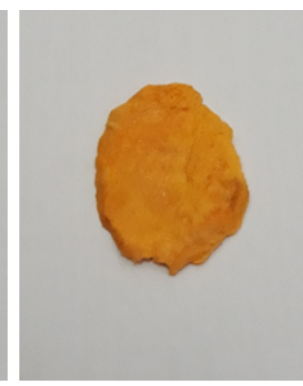

(b)

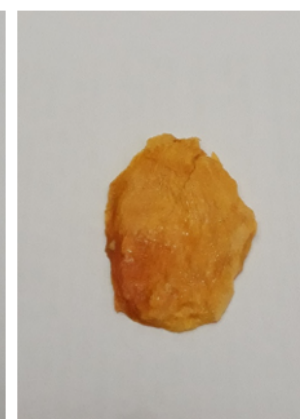

(e)

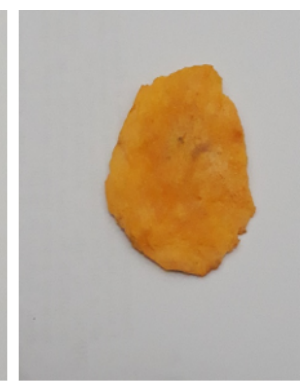

(c)

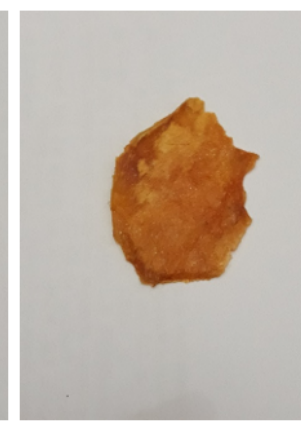

(f)
Figure 2: Freeze-dried mango with variation of pressures and times. Note: $13 \mathrm{~h}$ a) pressure on $25 \mathrm{~Pa}, b)$ pressure on $30 \mathrm{~Pa}, c)$ pressure on $35 \mathrm{~Pa}$, and for $17 \mathrm{~h}(\mathrm{~d})$ pressure on $25 \mathrm{~Pa}$, (e) pressure on $30 \mathrm{~Pa},(f)$ pressure on $35 \mathrm{~Pa}$.

Furthermore, varying pressures greatly affect the value of moisture content produced because the lower the pressure of an operating system, the lower the value of moisture content obtained and vice versa. This is supported by Lamilla et al. (2021) opinion that the pressure in the drying process affected moisture content. Thus, there is an influence relationship between time variation and pressure on the moisture content value produced in the freeze-dried mango slices sample. Overall, the dried mango sample has a moisture content value that meets the SNI (Standar Nasional Indonesia-Indonesian National Standard) No. 01-3710-1995. The maximum water content in dried or dried fruit products is $31 \%$ (BSN, 1995).

The correlation of moisture content values of each treatment showed that the average value of the moisture content in Treatment 2 was lower than the moisture content in Treatment 1 . Therefore, the time variation in Treatment 1 was relatively lower than Treatment 2, where the time was relatively longer. So, the faster the drying time would be affected, the higher the water content value, and otherwise.

\section{Mass balance}

The initial weight of the incoming product determined using the mass balance is the same as the weight of the product produced. In addition, it can predict the number of water that have evaporated due to the drying and sublimation process, two influential phases in determining the quality of dried products, based on water content standards following SNI.

The mass balance calculation assumed that the process is steady-state. The calculation is done with Equation (5) and Equation (6) using experimental data and applying these assumptions. Thus, the results are presented in Table 2.

Table 2 shows that both Treatment 1 and Treatment 2 fulfill the basic principle of mass balance, which is the amount of feed that enters the system (drying process) is the same as the amount that comes out of the system (product). This can be seen in the percentage of the final product's weight and the percentage of evaporated or wasted products due to the drying process. For example, the incoming feed was $293 \mathrm{~g}$, which is considered $100 \%$. Therefore, it can be seen in the number of lost or evaporated products with an average value of around $80 \%$ of the accumulated value of the wasted product sample. Meanwhile, the final product obtained after the drying process has an average value of around $17 \%$ accumulated throughout the sample. 
Table 2: Mass balance.

$\begin{array}{llllll}\text { Sample } & \begin{array}{l}\text { Initial mass mango } \\ \text { slices wet basis } \mathbf{( g )}\end{array} & \begin{array}{l}\text { Pressure } \\ \mathbf{( P a )}\end{array} & \begin{array}{l}\text { Mass of freeze-dried } \\ \text { mago slice dry basis } \mathbf{( g )}\end{array} & \begin{array}{l}\text { Percentage mass of freeze- } \\ \text { dried mango slices (\%) }\end{array} & \begin{array}{l}\text { Percentage of waste } \\ \text { products (\%) }\end{array} \\ \text { Treatment } 1 & 293 & 25 & 57.16 & 19.50 & 80.50 \\ (13 \mathrm{~h}) & 30 & 56.80 & 19.00 & 81.00 \\ & 35 & 54.70 & 18.70 & 81.30 \\ \text { Treatment } 2 & 25 & 47.90 & 16.00 & 84.00 \\ (17 \mathrm{~h}) & 30 & 49.13 & 17.00 & 83.00 \\ & 35 & 44.70 & 15.00 & 85.00 \\ \text { Average } & & 51.73 & 17.02 & 82.98\end{array}$

Note: E1A1 is 13 h with $25 \mathrm{~Pa}, \mathrm{E1A2}$ is $13 \mathrm{~h}$ with $30 \mathrm{~Pa}, \mathrm{E} 1 \mathrm{A3}$ is $13 \mathrm{~h}$ with $35 \mathrm{~Pa}, \mathrm{E} 2 \mathrm{A1}$ is $17 \mathrm{~h}$ with $25 \mathrm{~Pa}$, E2A2 is $17 \mathrm{~h}$ with $30 \mathrm{~Pa}$, 17 with $35 \mathrm{~Pa}$.

It can be said that the influence of time and pressure varies on the amount of outcome produced because the drying conditions differed from $25 \mathrm{~Pa}, 30 \mathrm{~Pa}$, to $35 \mathrm{~Pa}$, which can be classified as levels from low, medium, and high. So, high pressure in drying processing with low or moderate temperatures offers retention of most bioactive compounds, nutrients, and sensory characteristics (Błaszczak et al., 2020).

These results are not much different from previous studies conducted by Salazar et al. (2017) that the amount of water wasted in the freeze-drying process is $70 \%$ to $80 \%$. That is the case with Marques et al. (2006), in the process of drying with a freeze dryer, reaching $73.07 \%$ of wasted water.

\section{Color}

The color analysis of the freeze-dried mango slices sample was carried out to determine whether a color change occurred from Treatment 1 and Treatment 2. The sample's color analysis results were obtained by determining the values of $L^{*}, a^{*}, b^{*}$ and sensory analysis using the five senses of vision to see the preference of freeze-dried mango slices. The result of the $L^{*}, a^{*}, b^{*}$ value is shown in Table 3.

The result in Table 3 shows the color analysis of freeze-dried mango slices from nine different runs. The overall value of $L^{*}, a^{*}, b^{*}$ was positive $(+)$. The positive $L^{*}$ value indicates that the yellow color is more dominant. The positive value of indicator $b^{*}$ means that the overall mango sample is predominantly yellow. Meanwhile, the value of indicator $\mathrm{a}^{*}$ is also positive, indicating that the color of freeze-dried mango is more dominantly red_than green. The value of $\mathrm{b}^{*}$ should be negative. From the $\Delta \mathrm{E}$ value, it can be seen that a reasonably drastic decrease begins at the sample with a drying time of $17 \mathrm{~h}$ with all variations of pressure. These results can be attributed to a longer time in the drying process, which is $17 \mathrm{~h}$ with high pressure of $35 \mathrm{~Pa}$, causing the moisture content to remain high enough compared to the low pressure so that it affects the color of food.

Table 3: Color value of freeze-dried mango slices.

$\begin{array}{lllll}\text { Sampel } & \text { Color } & & & \\ & \text { L } & \text { a } & \text { b } & \Delta \text { E } \\ \text { E1A1 } & 72.81 & 15.41 & 53.64 & 91.77 \\ \text { E1A2 } & 68.27 & 17.10 & 55.47 & 89.62 \\ \text { E1A3 } & 72.82 & 14.49 & 58.35 & 94.46 \\ \text { E2A1 } & 70.94 & 12.25 & 54.73 & 90.57 \\ \text { E2A2 } & 66.58 & 14.53 & 48.35 & 83.62 \\ \text { E2A3 } & 56.58 & 17.00 & 39.66 & 71.25 \\ \text { Average } & 68.00 & 15.13 & 51.70 & 86.88\end{array}$

Note: E1A1 is 13 b with $25 \mathrm{~Pa}, \mathrm{E1A2}$ is $13 \mathrm{~b}$ with $30 \mathrm{~Pa}, \mathrm{E} 1 \mathrm{A3}$ is $13 \mathrm{~b}$ with $35 \mathrm{~Pa}, \mathrm{E} 2 \mathrm{A1}$ is $17 \mathrm{~h}$ with $25 \mathrm{~Pa}, \mathrm{E} 2 \mathrm{A2}$ is $17 \mathrm{~b}$ with 30 $\mathrm{Pa}, 17$ h with $35 \mathrm{~Pa}$.

So, it can be seen in the results of the study that the longer the freeze-drying process is carried out, the $\Delta \mathrm{E}$ value decreases. These results are compared with the results of previous studies by Salazar et al. (2017); the result of the $\Delta \mathrm{E}$ value is 22.59 . These results are similar to Kaewdam et al. (2013) research, drying the Nam Dok Mai type of mango with a freeze dryer results in a value of $\Delta \mathrm{E}$ ranging from 4.37 to 13.94 with each color parameter characteristic of $\mathrm{L}^{*}, \mathrm{a}^{*}, \mathrm{~b}^{*}$ being 78.92 , 3.53, and 38.42, respectively.

In Treatment 1 , the mango color did not change significantly throughout the treatment. But the color changed significantly in Treatment 2 . It can be seen in Treatment 2 the color of mango changed for all variations in pressure. For example, with a pressure of $25 \mathrm{~Pa}$, the Gedong Gincu had a bright orange 
color. With a pressure of $30 \mathrm{~Pa}$, the colors were not significantly different from that of $25 \mathrm{~Pa}$. However, it was different with a pressure of $35 \mathrm{~Pa}$, where the color tended to be dark orange. According to Ceballos et al. (2012), the high intensity of the color formed can be caused by the mechanism of the fast freezing process, which has a small pore structure so that it is easily dispersed.

The color of mango slices changing to a darker shade with higher pressure indicates that pressure affects the dried mango's quality. These results are consistent with Zhang et al. (2017) opinion that low temperature and pressure below the triple point of water rendering are excellent for freeze-dried products. Thus, the influence of time and pressure on the color change in the freeze-dried mango slices sample was found in Treatment 2. This is consistent with the opinion of Salazar et al. (2017) that the lower the chamber pressure in the freeze-drying process, the change in lightness in the color $(\Delta \mathrm{Eab})$ indicator will be low and also affect the dehydration of mangoes. Thus, short-time and low-pressure treatment samples have properties in maintaining better color stability.

\section{Hedonic test}

The freeze-dried mango slices were tested for their characteristics in the hedonic analysis of ten trained panelists by assessing the hedonic characteristics based on aroma, taste, texture, and color. Responses to hedonic tests are attached in questionnaires and with hedonic scales such as very dislike, dislike, rather like, like, and like very much (Ahmad et al., 2014).

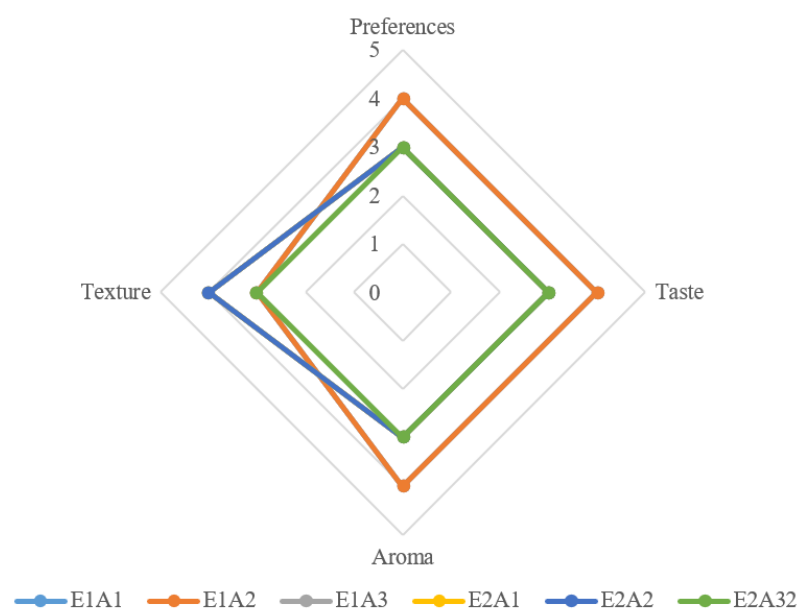

Figure 3: Hedonic results of freeze-dried mango slices.

The hedonic test results on freeze-dried mango slices showed that panelists liked the quality formed based on assessing preferences, tastes, flavors, and textures.
In preference, the panelists liked the sample in Treatment 1 with $13 \mathrm{~h}$ for all pressure variations. Meanwhile, the panelists preferred the sample's aroma in Treatment 1 with $13 \mathrm{~h}$ at a pressure of $25 \mathrm{~Pa}$ and $30 \mathrm{~Pa}$.

Panelists liked the aroma of Treatment 1 because it has more fragrance and distinctive aroma like fresh mango compared to Treatment 2. This is reinforced by the research of Mohammed et al. (2020) that drying time can affect the attributes of dried fruits, e.g., aroma, taste, and texture.

Finally, the panelists preferred the Treatment 2 in $17 \mathrm{~h}$ at pressures of $25 \mathrm{~Pa}$ and $30 \mathrm{~Pa}$ in terms of texture. The presence of a relatively hard texture is due to drying time on the mango fruit. This is reinforced by Mohammed et al. (2020) opinion that drying can improve the taste and texture of the persimmons and consequently influence over $80 \%$ of consumer acceptability of the dried products. So, conclusions can be explained on the overall hedonic test results. The panelists preferred the samples in Treatment 1 both regarding preferences, tastes, and flavors, but not on the resulting texture.

\section{Conclusions and Recommendations}

The freeze-drying process is the best alternative to other modern drying technologies that have proven suitable for drying foods that generally have high water and sugar content, such as mangoes. The resulting water level is set at $<31 \%$, according to the standard. The mass balance results have shown that the input is equal to the output if the processing is stable. The color produced is not very different from the standard Gedong Gincu mango type. It can be seen in the figure of freeze-dried mango preference of color, and the hedonic result showed the preference, taste, and flavor many panelists liked.

\section{Novelty Statement}

The investigation of this manuscript found that freeze-dried mango was calculated for mass balance yields were around $82.47 \%$ of the product wasted during the drying process, and the product yield was only approximately $17.53 \%$. The water content value was $6.17 \%$ to $7.13 \%$, below the Indonesian National Standard for dried fruit products $<31 \%$. The color produced is not very different from the standard Gedong Gincu mango type. Therefore, this freeze- 
drying technique can prevent decay, improve product quality, and extend the storage life more efficiently.

\section{Author's Contribution}

SS and HH conceptualized and designed the study, elaborated the intellectual content, performed literature search, data acquisition, data analysis, statistical analysis, manuscript revision and guarantor. APT conceptualized and designed the study, carried out literature search, experimental studies, data acquisition, data analysis, manuscript preparation, and manuscript review. WAMP carried out experimental studies, and manuscript review. All authors read and approved the final manuscript.

\section{Conflict of interest}

The authors have declared no conflict of interest.

\section{Reference}

Adinurani, P.G. 2016. Design and analysis of agro trial data: Manual and SPSS. Plantaxia, Yogyakarta, Indonesia.

Ahmad, D., P.N. Sari and P. Gilang. 2014. Sponge organoleptic test by using various types of emusifier on dough. J. Teknologi Pengolahan Minyak dan Lemak, 1: 1-8.

An, K., D. Zhao, Z. Wang, J. Wu, Y. Xu and G. Xiao. 2016. Comparison of different drying methods on Chinese ginger (Zingiber officinale Roscoe): Changes in volatiles, chemical profile, antioxidant properties, and microstructure. Food Chem., 197: 1292-1300. https://doi. org/10.1016/j.foodchem.2015.11.033

AOAC. 2000. Official methods of analysis 17th edition. The association of official analytical chemists. Gaithersburg, MD, USA. Methods 925.10, 65.17, 974.24, 992.16.

Azizah, E. 2016. Improving the quality of Gedong Gincu mangoes through endospermic culture. Jurnal Agrotek Indonesia, 1(1): 47-56. https:// doi.org/10.33661/jai.v1i1.254

Badan Standardisasi Nasional (BSN). 1995. Hand book of SNI dried fruit 01-3710-1995. BSN, Jakarta.

Błaszczak, W., P. Latocha, M. Jeż and W. Wiczkowski. 2020. The impact of highpressure processing on the polyphenol profile and anti-glycaemic, anti-hypertensive and anti-cholinergic activities of extracts obtained from kiwiberry (Actinidia arguta) fruits. Food Chem., 343:12842. https://doi.org/10.1016/j. foodchem.2020.128421

Ceballos, A.M., G.I. Giraldo and C.E. Orrego. 2012. Effect of freezeing rate on quality parameters of freezedried soursoup fruit pulp. J. Food Eng. 111(2): 360-365. https://doi. org/10.1016/j.jfoodeng.2012.02.010

Fernando, V.L. 2009. Analysis of vacuum freeze drying process aloe vera using condenser waste heat utilization. MT Thesis. Teknik Mesin Universitas Indonesia. Depok, Indonesia.

Kaewdam, S., C. Nitatwichit, J. Varith and S. Jaturonglumlert. 2013. Mathematical model of freeze drying on Mango. J. Agric. Res. Ext., 30(3): 56-67.

Lamilla, C.P., S.R. Vaudagna, S.M. Alzamora, M. Mozgovoj and A. Rodriguez. 2021. Effect of the high-pressure assisted-infusion processing on nutritional and antioxidant properties of mango cubes. Innov. Food Sci. Emerg. Technol., 71: 102725. https://doi.org/10.1016/j.ifset.2021.102725

Liliana, S.C., D.P.V. Munoz, A.A. Aponte. 2015. Structural, physical, functional and nutraceutical changes of freeze-dried fruit. Afr.J. Biotechnol., 14(6): 442-450. https://doi.org/10.5897/ AJB2014.14189

Marques, L.G., M.C. Silveira and J.T. Freire. 2007. Freeze-drying of acerola (Malpighia glabra L.). Chem. Eng. Process. 46(5): 451-457. https:// doi.org/10.1016/j.cep.2006.04.011

Mohammed, S., M. Edna and K. Siraj. 2020. The effect of traditional and improved solar drying methods on the sensory quality and nutritional composition of fruits: A case of mangoes and pineapples. Heliyon, 6(e04163):1-10. https:// doi.org/10.1016/j.heliyon.2020.e04163

Nawirska, A., A. Figiel, A.Z. Kucharska, A. SokolLetowska and A. Biesiada.2009.Drying kinetics and quality parameters of pumpkin slices dehydrated using different methods. J. Food Eng. 94(1): 14-20. https://doi.org/10.1016/j. jfoodeng.2009.02.025

Parniakov, O., O. Bals, N. Lebovka and E. Vorobiev. 2016. Pulsed electric field assisted vacuum freeze-drying of apple tissue. Innov. Food Sci. Emerg. Technol., 35(6):52-57. https://doi. org/10.1016/j.ifset.2016.04.002 
Pramulya, R., T. Bantacut, E. Noor and M. Yani . 2019. Material flow analysis for energy potential in coffee production. IOP Conf. Ser. Earth Environ. Sci., 399(012011):1-8. https://doi. org/10.1088/1755-1315/399/1/012011

$\mathrm{Pu}$, Y.Y. and D.W. Sun. 2015. Prediction of moisture content uniformity of microwave-vacuum dried mangoes as affected by different shapes using NIR hyperspectral imaging. Innov. Food Sci. Emerg. Technol., 33: 348-356. https://doi. org/10.1016/j.ifset.2015.11.003

Rasmikayati, E., B.R. Saefudin, H.J. Nadapdap and F. Awaliyah. 2020. Agribusiness behavior of mango farmers in the district of Panyingkiran Majalengka regency based on mango ownership. Sosiohumaniora, 22( 2): 206 -213. https:// doi.org/10.24198/sosiohumaniora.v22i2.25472

Rehman, Z.U., K. Akbar, A.U. Rehman, H. Waqas, A. Khan and A. Ali. 2021. Development and storage stability of diet mango juice. Sarhad J Agric. 37(1): 190-199. https://doi. org/10.17582/journal.sja/2021/37.1.190.199
Salazar, N.A., C. Alvarez and C.E. Orrego. 2017. Optimization of freezing parameters for freezedriying mango (Mangifera indica L.) slices. Drying Technol., 36(2): 192-204. https://doi.or g/10.1080/07373937.2017.1315431

Sandrawati, A., A. Suriadikusumah and D. Yuningtyas. 2017. Identification of agroecological zones and land suitability of the Arumanis mango commodity (Mangifera indica L.) in Probolinggo Regency. Soil Rens, 15(1): 29-37. https://doi.org/10.24198/soilrens.v15i1.13342

Valentina,V., A.R. Pratiwi, P.Y. Hsiao, H.T. Tseng, J.F. Hsieh and C.C. Chen. 2016. Sensorial characterization of foods before and after freeze-drying. J. Aust. Food Sci., 1(6):1-5.

Zhang, M., H. Chen, A.S. Mujumdar, J. Tang, S. Miao and Y. Wang. 2017. Recent developments in high-quality drying of vegetables, fruits, and aquatic products. Crit. Rev. Food Sci. Nutr., 57(6): 1239-1255. https://doi.org/10.1080/104 08398.2014 .979280 